\title{
A Review of Solid Waste Management Strategies in Nigeria
}

\author{
Nwosu, Agnes Ogechukwu ${ }^{1 *}$ Chukwueloka, Henry Emeka ${ }^{2}$ \\ 1. Faculty of Marine Environmental Management, Nigeria Maritime University, Okerenkoko Delta State-Nigeria \\ 2. School of Basic Science, Nigeria Maritime University, Okerenkoko, Delta State-Nigeria
}

\begin{abstract}
The global population and increased urbanization have resulted in the increased production of municipal solid waste, thus, becoming a critical issue as a result of its poor management and inappropriate disposal. This is particularly the case of developing countries. This study assessed Solid Waste Management (SWM) strategies commonly adopted by different state waste management Authorities in Nigeria with a view to develop a sustainable roadmap for the management of solid waste in Nigeria. It assessed the Traditional Solid Waste Management Strategy (TSWMS), Waste Minimisation Strategy (WMS) as well as the Technological Strategy (TcS) employed, laying focus on their challenges and benefits. The study depended on a desktop study approach; hence, data were obtained from secondary data as the main source of information with emphasis on published journals, conference papers, newspaper posts and statutory reports from government agencies relevant to the current study. Results from the review showed that waste management across various parts of Nigeria is poor, interwoven with several challenges at all phase of the management process with little benefits recorded on alternative SWM strategy. The reason for the low success rate of some of this management strategies were noted as; increase in population, area covered, increase in urbanization and industrialization, tenure of government, over dependence on government authorities for waste management, finance and other factors of the environment. Although most waste authorities rely heavily on the TSWMS, WMS and the TcS showed a better and promising alternative strategy when inculcated into the already existing strategy. Based on this finding, a roadmap for the actualization of a sustainable integrated solid waste management strategy was recommended for adaptation and adoption by the Nigerian SWM Authorities and Agencies.
\end{abstract}

Keywords: Nigeria, Solid Waste Management, Traditional Solid Waste Management Strategy, Waste Minimisation Strategy, Technological Strategy, Waste Authorities.

DOI: $10.7176 / \mathrm{JEES} / 10-6-11$

Publication date: June $30^{\text {th }} 2020$

\section{Introduction}

Waste is any substance or material which requires to be disposed of as being broken, worn out, contaminated or otherwise spoilt and as such lost its usefulness (Anifowose et al., 2011). It could be in liquid or solid form and could be hazardous. These classification ranges from garbage or refuse from homes and other places where human or animal lives exist. On the other hand, solid waste as described by State of Vermont Agency of Natural Resources Department of Environmental Conservation (2012) is any tangible and non-free flowing unwanted materials or substance that results from human activities. It is referred to as Municipal Solid Waste where its sources are generated from - commercial, agricultural, and industrial operations (Singh et al., 2011). To this end, population growth and economic development is a major contribution to solid waste generation in urban areas (The World Bank, 2019). Thus, Municipal solid waste is usually generated from human settlements, small industries, and commercial activities.

In Africa, rapid urban growth has exacted massive pressure on cities, towns and surrounding areas (Aliyu \& Amadu, 2017; Saghir \& Santoro, 2018). This has led to increased urban waste generation leading to health hazards, underground water pollution, and affected air and aesthetic qualities (Mazhindu et al., 2012). The inability to properly manage these wastes generated in developing countries such as Nigeria creates great concern (Amasuomo \& Baird, 2016). Nigeria, with a population exceeding 180 million (National Bereau of Statistics, 2018) is one of the largest producers of solid waste in Africa (Bakare, 2020). Despite a host of policies and regulations, solid waste management in the country remains a huge challenge to the authorities, stakeholders and the entire public.

It has been recorded that, Nigeria generates over 32 million tons of solid waste yearly, and only a fraction is collected (Bakare, 2020). Most of these wastes are generated by households and in some cases, by local industries, artisans and traders who litter the immediate surroundings. Improper collection and disposal of municipal wastes has led to different levels of environmental challenge such as blockade of sewers, drain networks and the choking of water bodies (George, 2010). Although, the country lacks a well-coordinated waste management system, Solid Waste Management (SWM) is under the purview of Ministry of Environment at the Federal and State levels and Environmental Health Department at Local Government level under established legislations and guidelines relating to waste management. Some of these legislations include: the Harmful Waste Act (Special Criminal Provisions, etc of 1988), the National Environmental Standards and Regulations Enforcement Agency (NESREA) 
Act 2007 (NESREA Act, repealed the Federal Environmental Protection Act of 1988), Environmental Impact Assessment act of 1992, National Environmental (Sanitation and Wastes Control) Regulations, 2009 and the National Environmental Protection Regulations (Pollution Abatement in Industries and Facilities Generating Waste).

Drawing from the directive of the Federal Government to the states for the establishment of waste authorities, all states in Nigeria have established waste authorities under the Ministry of Environment (National Environmental Standards and Regulations Enforcement Agency, 2007). Some of these Waste Authorities include; Abuja Environmental Protection Board, Anambra State Waste Management Authority (ASWAMA), Lagos State Waste Management Agency (LAWMA), Oyo State Solid Waste Management, Rivers State Environmental Sanitation Authority, Kano State Refuse Management and Sanitation Board to name a few. The emergence of waste Authorities in most states in Nigeria has brought about several strategies best suitable for solving the problems of waste management in the state. These strategies include; The traditional waste management strategies consisting of waste generation, collection, transportation and disposal, the Waste minimisation strategy consisting of waste reduction, reuse, recycle and recovery, and technological strategy consisting of the application of Geographical Positioning Systems (GPS), Geographical Information System (GIS) and Remote sensing technologies.

However, these state waste authorities have had challenges on the management of waste in their jurisdiction which have been captured by several scholars (Agunwamba, 1998; Kofoworola, 2007; Imam et al., 2008; Ogwueleka, 2009b; Solomon, 2009), have identified these problems and recommended ways to solve the problems associated with waste management using these strategies. Although these strategies worked for some time, however, it seems to be failing because of the large area of land to cover, the population of Nigeria, bureaucratic nature of government policies and its implementation, government jurisdiction and high dependence on capital (capital intensive) (Anestina et al., 2014).

To this effect, the study assessed SWM strategies commonly adopted by different state waste management Authorities in Nigeria with a view to develop a sustainable roadmap for the management of solid waste in Nigeria. It assessed the Traditional Solid Waste Management Strategy (TSWMS) which includes waste generation/characterization, collection, transportation and disposal, Waste Minimisation Strategy (WMS) which includes waste reduction, reuse, recycle and recovery as well as the Technological Strategy (TcS) which applies GPS, GIS, Remote sensing, laying focus on their challenges and benefits. This review study depended solely on a desktop review approach, secondary data such as published journals and statutory reports from government agencies were employed.

\section{Waste Management Strategies in Nigeria}

The handling of SWM in Nigeria calls for immediate attention and the adoption of the best practicable environmental approach towards preserving the environment. In achieving a sustainable SWM strategy, all steps of the management process must be fully functional and effective. They include; solid waste generation and characterization, solid waste collection and transportation, and solid waste disposal/treatment (Federal Ministry of Environment, 2000). Researchers (Sha'Ato et al., 2007; Olanrewaju \& Ilemobade, 2009; Uwadiegwu, 2013; Onuigbo \& Bello, 2014) have reported a similar pattern of management at the different steps of solid waste management. This section will briefly examine the management strategies employed by various Solid Waste Authorities in Nigeria. They are; TSWMS, WMS, TcS.

\subsection{Traditional Solid Waste Management Strategy in Nigeria (TSWMS)}

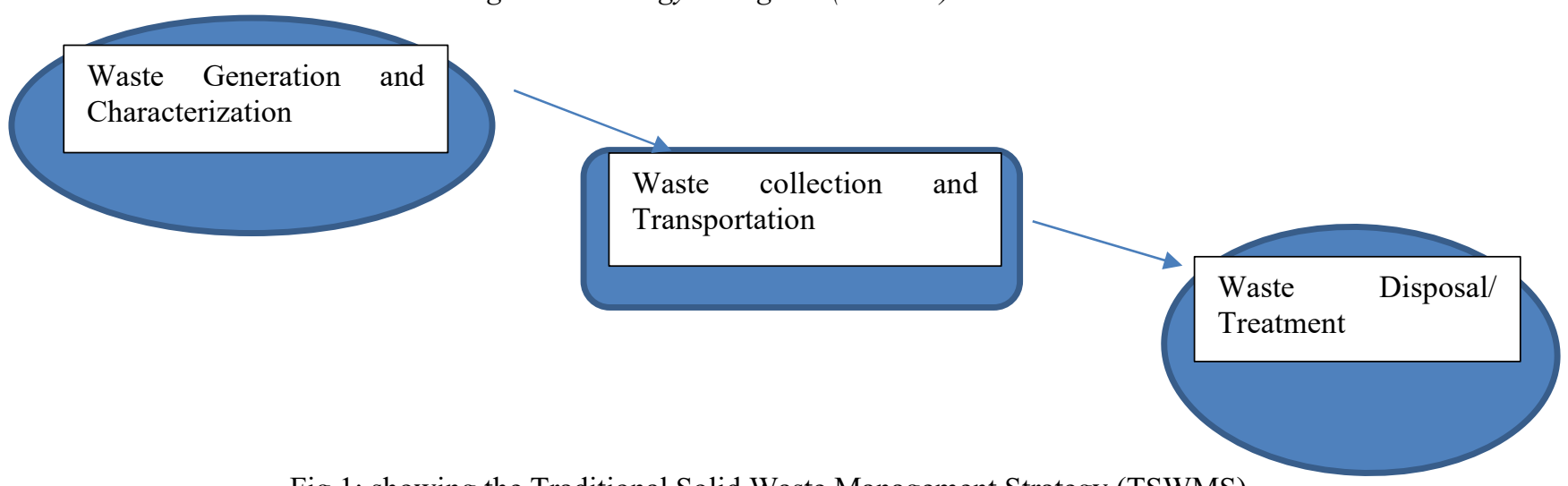

Fig 1: showing the Traditional Solid Waste Management Strategy (TSWMS)

Fig 1 above gives an illustration of a typical TSWMS employed by waste authorities in various parts of Nigeria. Most often, the process of waste management starts with waste generation, waste characterisation seldom takes place, followed by the collection of this waste either in bags or receptacles and then to waste transportation 
and finally to disposal sites. This method often employed has presented some benefits as well as problems to the waste management process.

\subsubsection{Waste Generation and Characterisation}

Waste generation and characterization is a fundamental step taken for effective waste management. Sha' Ato et al. (2007) carried out a study of waste generation profile of Makurdi, in North-Central Nigeria. He reported that the bulk of the solid waste generated in the area originated from households than from commercial, institutional and industrial premises. These wastes, constituted majorly, various putrescible materials, ash, dust and sand. On the other hand, a study of solid medical waste showed that health outfits and hospitals in the Federal Capital Territory, Abuja, generate a sizeable amount of solid waste collected daily which poses serious harm to the environment and man (Bassey et al., 2006). The study stated that, of the total solid waste generated daily, 26.5\% was hazardous in nature and waste segregation was found not to be practiced by any of the hospitals sampled. Similarly, Fadipe et al. (2011) pointed out that medical wastes in Osun state are not being properly disposed of and as such, pathology wastes such as unclaimed dead bodies, placentas, umbilical cords are being dumped into unlined pits and other wastes in open dumps.

A comparative analysis of municipal solid waste (MSW) composition in three local government areas in Rivers State revealed that waste generation rate was $0.45,0.98$ and $1.16 \mathrm{~kg} / \mathrm{capita} /$ day for Emougha, Obio/Akpor and Port Harcourt, respectively (Babatunde et al., 2013). The most prominent categories identified were organic waste, paper and nylon. Mean percentage composition was 59, 65.5,65 for organic waste, 6,11 and 13\% for paper and 14, 16 and 12\% for nylon in Emougha, Obio/Akpor and Port Harcourt LGAs, respectively. They pointed out that there are potentials for resource recovery and energy generation. Similarly, Sha'Ato (2007) noted that of the waste from households, a substantial proportion consists of various putrescible materials (36-57\%) and suggested composting as the best form of waste management.

The rate of generation of plastics, waterproof materials and diapers has assumed an upward trend (Nnaji, 2015). Most food waste was found to constitute close to 50 percent of overall municipal solid waste in Nigerian cities (Nnaji, 2015; Aliyu, 2010). Due to the dysfunctional state of many municipal waste management authorities, many cities in Nigeria have been overrun by open dumps. There is a need for both government and individuals to adopt holistic and sustainable waste management strategies in order to safeguard public/environmental health (Nnaji, 2015). Sustained cooperation could be developed among all key actors (government, waste managers, public health workers and inhabitants) to implement an economic, sustainable, and reliable management practices in Nigeria (Olukanni \& Mnenga, 2015). A provision of sizable funds by the government and proper education to the people among others will help in sustainably managing the solid waste problem.

2.1.2 Solid Waste Collection and Transportation

Waste collection and disposal are the major problems faced by developing countries in solid waste management (Aliu et al., 2014). Yet, it is one of the most difficult operational problems faced by most urban areas in Nigeria (Ogwueleka, 2009a). Udoh and Inyang (2016) reported some of the solid waste collection problems which include; singular dumpsite in the study area resulting to inherent routing issues, singular type of waste receptacle used for all categories of waste, size of bins not considered for overpopulated areas leading to opened receptacles, and overflow of waste which subsequently serves as a breeding ground for rodents, fleas and vermin. On the other hand, (Olukanni et al., 2016) as well, identified local factors affecting solid waste collection ranging from poor management infrastructure, people's attitude to waste management, weak policies, lack of sufficient funds to power the waste management sector, household economic status and Adhoc location of facilities.

In remedying these problems stated, (Egbu \& Okoroigwe, 2015) noted that the collection of urban household solid waste traditionally rests on government agencies designated with such responsibility. Adding that for effective waste collection, household patronage of informal private solid waste collectors as against governmentprovided community/street collection containers were to be encouraged. Similarly, Aliu et al. (2014) revealed several strategies that have been applied for efficient municipal solid waste management in developing economies adding that strong positive perception of public-private partnership as a waste collection policy framework to solve solid collection problems. Olukanni and Mnenga (2015) also notified that there is no investment presently made on the existing development plan to initiate a modern waste collection system thereby calling for innovative remedies to curb the problem. Other remedies to the underlining problems surrounding the collection and transportation of solid waste in Nigeria include; the integration and collaboration of all the stakeholders through broad-based sensitization and communication of effective and sustainable waste management (Hammed et al., 2016), as well as need for SWM cost-sharing between the government and the people, enforcement of sanitary laws and adequate fund allocation for all concerned agencies, the involvement of Private Sector Participation (PSP), and awareness campaigns (Oloruntade et al., 2014).

Although the collection of solid waste and transportation of solid waste may share the same setbacks, Ayantoyinbo and Adepoju (2018) identified a problem peculiar to solid waste transportation and logistics which is street traffic especially in urban areas affects waste logistics. however, they noted the roles the government and the private sector could play for the effective management of solid waste. 


\subsubsection{Solid Waste Disposal/Treatment}

After waste is generated, collected and transported, the final step in the management process is the disposal of the waste. In some Nigerian cities, the status of waste dumpsites, the continual advent of illegal dumpsites havee been as a result of a failed waste management system (Nnaji, 2015). Illegal dumpsites result to loss of aesthetic beauty, endangers man and the environment, causing the spread of diseases and the pollution of the entire environment (Momodu et al., 2011). Port Harcourt, the capital of Rivers state was at a point in time referred to as the Nigerian garden city because of its clean environment, beautiful vegetation and serene nature. However, this is no longer the case there, as there exist pockets of refuse dumps litter several areas of the once beautiful city (Ayotamuno \& Gobo, 2004).

According to Nnaji (2015), more than 50 percent of residents of Maiduguri in Northern Nigeria and Ughelli in Southern Nigeria dispose of their waste in open dumps. Although open dumpsites disposal method is a commonly adopted method of disposal in Nigeria and other developing countries, which involves people disposing of their waste on open grounds most often indiscriminately, they are generally unsanitary, unsightly and smelly, attracting rats, insects, snakes and flies (Udoh \& Inyang, 2016). Onwughara et al. (2010) reported other nonobvious implications of open dumpsites such as landfill gases and leachate which contributes to global warming and urban ozone problem thereby harming both humans and the natural environment. Similarly, (Aluko et al., 2003) reported characteristics of leachates found at dumpsites at Ibadan, Nigeria and the serious problems they possess on contaminating the land and water around them. Dumpsites in the southern part of Nigeria are largely unsuitable owing to the highly waterlogged characteristics of the region (Leton \& Omotosho, 2004). This calls for geological assessment of areas before designing dumpsites.

Although, there are many other forms and methods of waste disposal outside landfilling, such as composting (Sha'Ato, 2007), waste reuse, source reduction and recycling (Longe et al., 2009) and incineration (Somorin et al., 2017; Onwughara et al., 2010), the option chosen should be beneficial to the environment and should require less energy, less resource use and limited pollution rate. As observed by Kofoworola (2007), the treatment of waste does not exist, as such, collected waste that are transported to dumpsites are burnt most often to reduce the volume of waste which results in air pollution and the release of harmful gases to the atmosphere. To this effect, Longe et al. (2009) advise the adoption of waste reduction, recycling and reuse as an alternative.

2.1.4 Constraints and Remedies of the traditional solid waste management

The overall management of solid waste in Nigeria is poor (Amasuomo \& Baird, 2016). Various studies (Oyeniyi, 2011; Oguntoyinbo, 2012; Amuda et al., 2014; Olukanni et al., 2016) have highlighted various challenges facing SWM in Nigeria across various states. Some of these challenges include inadequate environmental policies and legislations (Agunwamba,1998; Nzeadibe \& Anyadike, 2012; Ezeah \& Robert, 2014), which points out loop holes in policies and non-existence of policies in some states towards waste management. Although good policies exist, implementation remains a challenge. Other challenges include poor funding, low level of government support, limited environmental awareness, inadequate facilities, corruption, politics, inappropriate technology, urbanization and low public participation (Ayotamuno \& Gobo, 2004; Kofoworola 2007; Imam et al. 2008; Ogwueleka, 2009b; Solomon, 2009).

Public awareness and participation is one of the remedies to the problems of waste management in Nigeria, Amalu and Ajake (2014), pointed the need for community education programs to adequately educate the people on environmental issues. Ezeah and Roberts (2014) revealed that there exist low levels of public education on municipal solid waste among the sample population in Abuja, as such, proposed a sustained public education on waste prevention, management and reuse. In the same line, Nwosu and Okoye (2019) proposed a framework for sustainable public participation in waste management. As it is evident in various other studies, (Wahab \& Kehinde, 2014; Amuda et al., 2014; Maiyaki et al., 2018), where they promote public participation, non-governmental participation, private sector participation and stakeholders participation in waste management over the years, the problem of solid waste management still exist.

Effective solid waste management can also be achieved through citizen mobilization and environmental education, strengthening of public agencies, a responsible government, logistics and infrastructural improvement, legislation, appropriate technologies, monitoring and surveillance (Uwadiegwu, 2013). Also, there is a need for a holistic program commonly ignored in waste programs that integrates all the economic, technical, cultural, social and psychological factors in conjunction with the adoption of a more modern management practice so as to achieve efficiency in waste management (Agunwamba, 1998). 


\subsection{Waste Minimisation Strategy (WMS)}

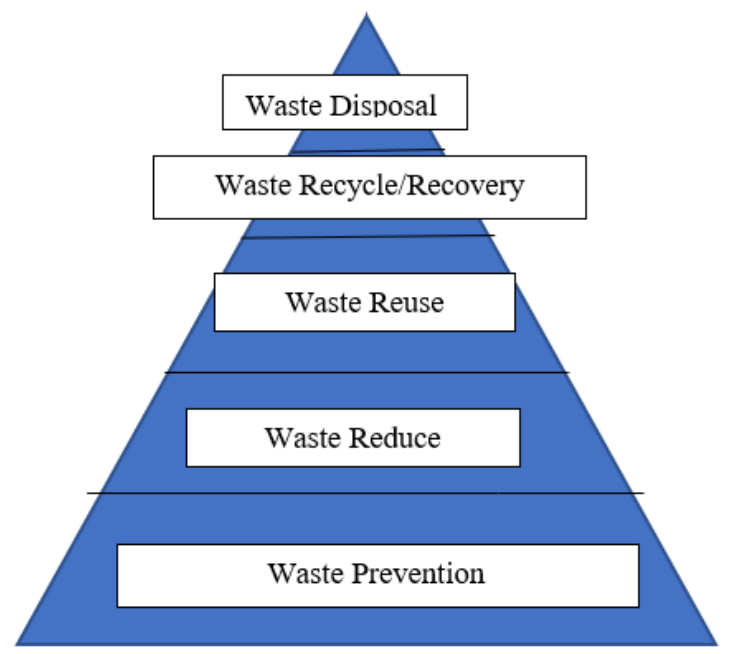

Fig 2: showing Waste Minimisation Strategy (WMS)

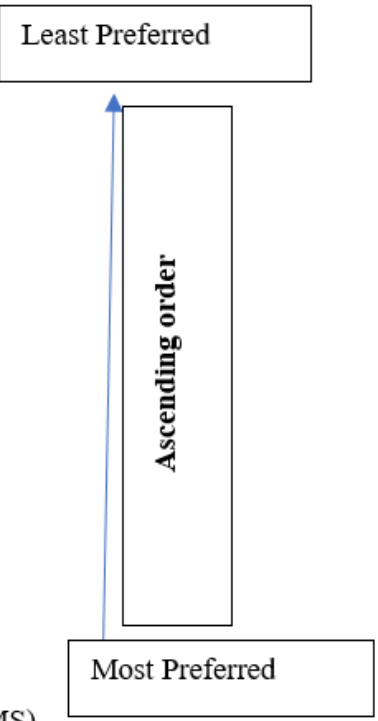

The value of solid waste can be derived at the same time as protecting the environment and man. The WMS illustrated above in Fig 2, gives a clear view of a sustainable waste management process if carried out well. Not only will the volume of the waste be reduced, the method opens up avenues where waste can be revalued into other purposes before disposed of.

Awopetu et al. (2013) revealed the perception of the public at Makurdi, North Central Nigeria, on the waste minimisation strategy option, which consists of waste reduction, reuse and recycling, of which, more than $80 \%$ of the sampled population were in support of this strategy and indicated interest as a more sustainable approach to managing waste as compared to other traditional strategies. As wsilling as the respondents were towards this strategy, Awopetu et al. (2013) identified that the infrastructure and societal means needed to promote this strategy were limiting factors that prevented its actualization. Olukanni et al. (2018) also, identified other major constraints in implementing this strategy, such as the cost of having a material recovery facility and technical expertise. However, Olukanni et al. (2018) established that the major key to a successful Waste Minimisation strategy was adequate waste characterization.

Olanrewaju and Ilemobade (2009) revealed in their study the success of Ondo State Integrated Waste Recycling and Treatment Project (OSIWRTP) in transforming the waste generated in the state to valuable products using the concept of sustainability, environmental protection, economic development, technical and technological improvement as a baseline. According to Olanrewaju and Ilemobade (2009), this waste recycling method eliminated the problems associated with open dumpsites which were unhygienic and inefficient posing a lot of harm to the people of Ondo state. Kofoworola (2007) acknowledged the informal recycling and recovery of waste in Lagos state which is yet to gain the support of the state government in charge and the waste authorities in place. To this end, only paper, metals, plastic and glass are recovered and recycled because of their high market value. Similarly, Nzeadibe (2009) revealed the informal recycling existence of solid waste in Enugu state which consists of scavengers/waste pickers, artisans, middlemen who recover plastics, metals, soles and textiles from landfills and illegal dumps within the state. Rigasa et al. (2015) on the other hand, recommended the integration of 'Almajiri' into waste minimisation strategy as they can serve as resource recovery agents in this strategy.

Olukanni et al. (2018) in their study, identified the benefits of minimisation strategy to the economy through composting. The study which was carried out in six South-Western states in Nigeria, recommended composting of biodegradable waste in the region as a waste management strategy which will benefit the economy as well as agricultural production. Onwurah et al. (2006) also, conducted another study at the South Eastern region of Nigeria, where the benefits of Minimisation Strategy also included the bioconversion of biodegradable waste to compost and biogas which will involve communities, industries and Small and Medium-scale Enterprise (SMEs) that have the capacity of integrated environmental technologies. Also, Olanrewaju and Ilemobade (2009) revealed some of the other forms of recycling activities at Ondo state. They include; composting from kitchen and yard waste, conversion of plastics to pellets, casting and recasting of metals into desirables and turning landfill gases into renewable energy.

Somorin et al. (2017) elaborated more on the potentials of waste to energy using incinerators. They estimated the electricity generation, depending on the amount of waste generated for different states in Nigeria which varied from 31 - $205 \mathrm{MW}$. Also, Suberu et al. (2012) reported the potentials of municipal solid waste for power generation considering the process of thermo-chemical conversion as an alternative to landfilling and dumps. Somorin et al. 
(2017) and Suberu et al. (2012) also reported an approximate of 442 MW can be achieved from Lagos state with a population of over 16 million as recorded in 2006 since the amount of waste generated is directly proportional to the population of the area.

Although landfilling is considered the cheapest and most convenient form of waste disposal, it has by far, more disadvantages to human health and the environment than waste recovery and recycling (Onwughara et al., 2010). The concept of waste recovery, recycling and waste to energy is relatively new in the practise of waste management in Nigeria (Suberu et al., 2012), due to challenges such as lack of the necessary facilities and equipment required for recycling, lack of technical know-how, lack of funding, and support from the government (Suberu et al., 2012 and Kofoworola, 2007). The advantages however, surpass the set-backs and should be considered. These methods have the potential of attaining the Millennium Development Goals relating to job creation, poverty alleviation, and sustainable environment (Nzeadibe. 2009), save energy, reduction in waste, cost and pollution (Olanrewaju \& Ilemobade, 2009) as well it could serve as a lasting solution to the electricity challenges of the country (Ben-Iwo et al., 2016; Somorin et al., 2017).

\subsection{Technological Strategy $(T c S)$}

Of all the modern management practices assessed, Waste Recovery, Recycling, Radio Frequency Identification (RFID) and Communications Technologies, Global Positioning System (GPS), Geographical Information System (GIS) and Remote Sensing Technologies are the relatively modern technologies adopted by studies to solve problems associated with waste management globally. Global Positioning System (GPS), Geographical Information System (GIS), and Remote Sensing, used most times together, are multi-functional technologies that have been applied in various fields to solve problems in record time at a lesser cost (Dutta \& Goel, 2017). Globally, studies have shown they can be applied at each step of the TSWMS process; at estimation of waste generation (Shoba \& Rasappan, 2013), waste storage (Deswal \& Laura, 2014), waste collection and route optimization (Nguyen-trong et al., 2016) using multi-agent based modeling and simulation, and dumpsite selection/waste disposal (Nishant, et al., 2010).

In Nigeria, Thompson et al. (2013) developed a system for waste management authorities at Ondo state Nigeria to help plan and solve problems associated with waste management. Using GIS technology, they developed a system that solved waste bin allocation and relocation, communication between the public and authority in charge as well as separation of recyclable waste. In route optimization, GIS is perceived as the most appropriate for locating least-cost travel routes for waste transport and disposal (Achi et al., 2012). Using preset criteria such as the distance of the site from a street at $30 \mathrm{~m}$, surface water at $160 \mathrm{~m}$, major roads at $200 \mathrm{~m}$ and absence of important economic or ecological features as to determine the best site and route for waste disposal and transportation, Achi et al. (2012), proposed Sam-Ewang and Ita-Ika disposal sites at Abeokuta, as best site after they met all stated criteria.

Based on suitable criteria, many dumpsites have been assessed and proposed as best for waste disposal using GIS and Remote Sensing technologies. At the Federal University of Technology, Minna, Gidan Kwano Campus, certain criteria were used which included slope, built-up-area, road networks, geological maps to determine and select using GIS, suitable sites for waste disposal (Onuigbo \& Bello, 2014). Similarly, using Multi-Criteria Analysis (MCA) and data from topographical map, remotely sensed imagery and soil map, Zumo and Vokna (2014), identified a suitable site for solid waste disposal at Yola, Nigeria. Various studies at other parts of Nigeria, (Babalola \& Busu, 2011; Ojo et al., 2014; Usman \& Kumar, 2015) applied the Multi-Criteria Analysis (MCA) or Multi Criteria Decision-Making methodology in the selection of suitable waste disposal sites for sustainable waste management. Some of the criteria analysed include; distance to river, railroad, existing dumpsite, airport, major road, advance road, slope, soil type, population, future urban expansion, geology, drainage, underground water table, geomorphology and lastly land-use types.

Although the challenges of disposal of solid waste has been a huge problem in Nigeria, the application of GIS and Remote Sensing Technologies has remediated this problem by spatially locating suitable sites for waste disposal (Zumo \& Vokna, 2014; Onuigbo \& Bello, 2014), as a suitable decision making tool for management and an analysis tool that facilitates planning processes (Babalola \& Busu, 2011; Onuigbo \& Bello, 2014), reduction of operating cost and time taken for operations (Kaoje et al., 2016) and a cheap source of data collection (Abiodun, 2000). Babalola and Busu (2011) also revealed the efficacy of GIS and Remote sensing for dumpsite identification and selection process that can be easily manipulated and replicated in other areas and countries for siting purposes.

There is a dearth in literature on the challenges of applying this technology in waste management. GIS and Remote Sensing Technologies do not provide for proper identification of all sources of waste generated as well as the actual volume generated daily which has affected data gathering and processing (Oyinloye \& Tokunbo, 2013), there also exist; limited manpower, funding and inadequate hardware and software facilities for data manipulation and processing (Abiodun, 2000) and most importantly lack of education and indigenous research in Nigeria of GIS and Remote Sensing Technologies (Asiyanbola, 2014). Also, despite the advancement of GIS and Remote sensing technologies in solving waste management problems globally, there are specifically reluctances in applying 
Remote sensing and GIS in solid waste management and integrated management strategies in Nigeria.

\section{Sustainable Roadmap for SWM}

Many solid wastes Authorities in Nigeria such as Abuja Environmental Protection Board, Anambra State Waste Management Authority (ASWAMA), Lagos State Waste Management Agency (LAWMA), Oyo State Solid Waste Management, Kaduna State Environmental Protection Authority, Rivers State Environmental Sanitation Authority, Kano State Refuse Management and Sanitation Board employ the TSWMS as the first line of approach in the management process. To this effect, the waste management process and strategy have been tagged poor (Amasuomo \& Baird, 2016) due to the continued emergence of illegal dumps, blocked drainages, and deteriorated environment and public health that is as a result of poor management. Even with the challenges attached to the TSWMS, when other strategies are employed, they could be faced with larger issues if not applied right.

The constraints and benefit of each strategy are highlighted in the table below;

Table 1: Some Constraint and Benefit of Each Waste Management Strategy in Nigeria

\begin{tabular}{|c|c|c|c|}
\hline $\mathrm{S} / \mathrm{N}$ & $\begin{array}{l}\text { SOLID WASTE MANAGEMENT } \\
\text { STRATEGY }\end{array}$ & CONSTRAINT & BENEFIT \\
\hline 1. & $\begin{array}{l}\text { TRADITIONAL WASTE } \\
\text { MANAGEMENT STRATEGY. } \\
\text { a. Generation/Characterisation } \\
\text { b. Collection, } \\
\text { c. Transportation and Disposal }\end{array}$ & $\begin{array}{l}\text { Heavy reliance on government } \\
\text { policies and authorities for } \\
\text { implementation, Segregation of } \\
\text { waste is nearly impossible, no } \\
\text { coordination of the different } \\
\text { steps since they are most times } \\
\text { not exclusive, public and } \\
\text { Limited awareness, } \\
\text { environmental } \\
\text { corruption etc }\end{array}$ & $\begin{array}{l}\text { Reasonably cheap. } \\
\text { No technical know-how is } \\
\text { required. }\end{array}$ \\
\hline 2. & $\begin{array}{l}\text { WASTE MINIMISATION } \\
\text { STRATEGY } \\
\text { a. Waste prevention } \\
\text { b. Waste reduction } \\
\text { c. Waste reuse } \\
\text { d. Waste recycle/recovery }\end{array}$ & $\begin{array}{l}\text { a. nil } \\
\text { b. nil } \\
\text { c. nil } \\
\text { d. expensive, technical know- } \\
\text { how is required, corruption, } \\
\text { reliance on the government }\end{array}$ & $\begin{array}{l}\text { a. Cheap, no technical know-how } \\
\text { is required. } \\
\text { b. No technical know-how is } \\
\text { required. } \\
\text { c. No technical know-how is } \\
\text { required. } \\
\text { d. provides an alternate source of } \\
\text { revenue and resource while } \\
\text { safeguarding the environment. }\end{array}$ \\
\hline 3. & $\begin{array}{l}\text { TECHNOLOGICAL STRATEGY } \\
\text { a. Application of GPS } \\
\text { b. Application of GIS } \\
\text { c. Application of Remote } \\
\text { sensing }\end{array}$ & $\begin{array}{l}\text { Technical know-how is required, } \\
\text { Expensive, Hardware and } \\
\text { Software are limited }\end{array}$ & $\begin{array}{l}\text { Easy and cheap source of data } \\
\text { collection tool especially when } \\
\text { covering a large area and } \\
\text { population, saves time and energy }\end{array}$ \\
\hline
\end{tabular}

Notwithstanding all the constraints listed above, all three strategies can be employed at different stages of the management process for optimal benefit to the waste management process in Nigeria as can be seen in Fig 3 below. 


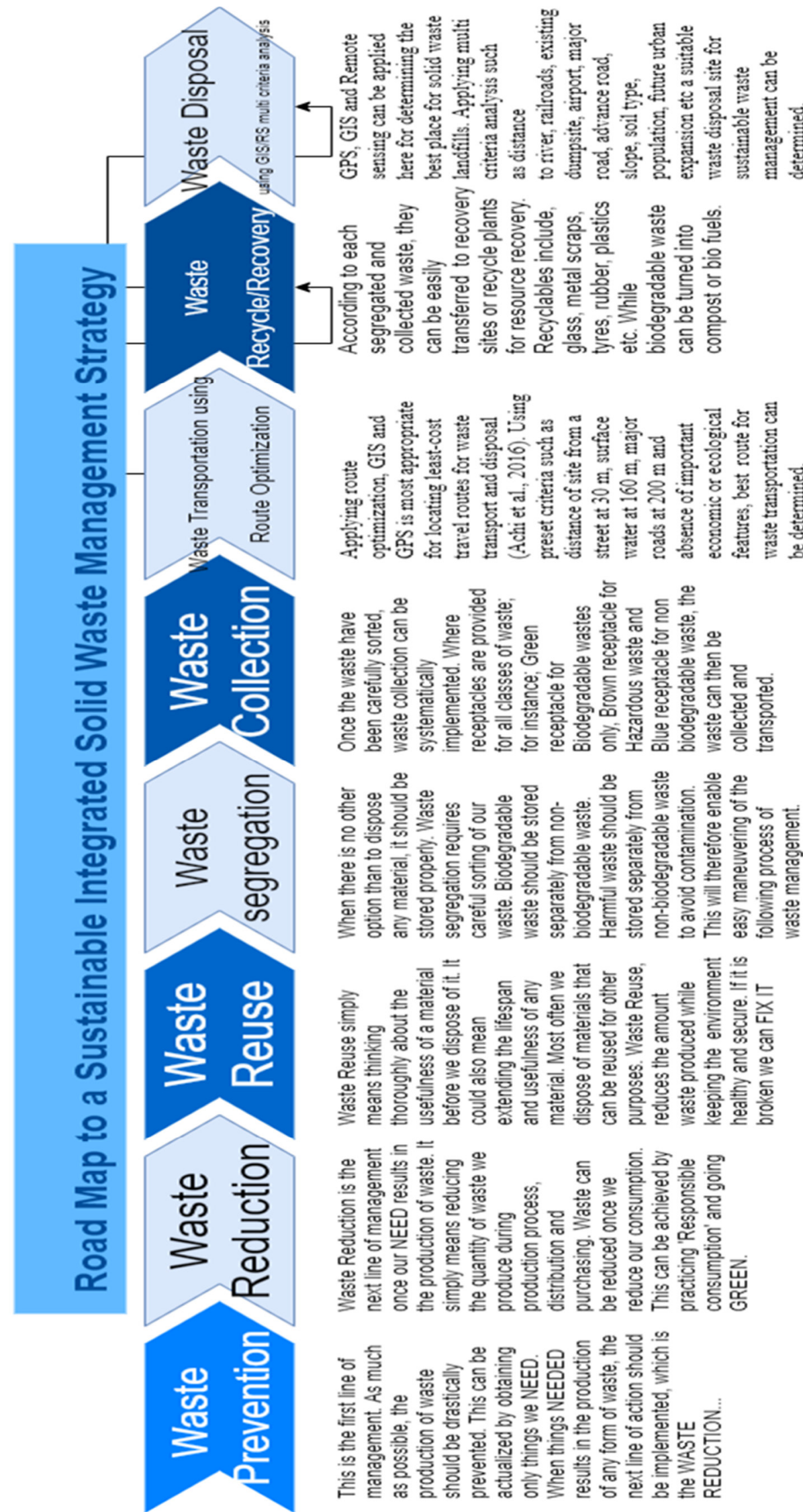

Fig 3: showing a road map to a sustainable integrated solid waste management strategy.

The Fig 3 above synchronized all waste management strategies, that, in one way or another, is employed by the Waste Authorities in Nigeria. Drawing from the rich benefits of the WMS to both the environment and the 
public, the researcher developed a Roadmap strategy starting from Waste prevention to Waste reduction and then to Waste reuse phase within the WMS process. This goes a long way to reducing the volume of waste that would have occurred if this Road map is to be dutifully followed. Drawing from the TSWMS, the researcher introduces Wastes segregation which will be carried out at the point of Waste generation. This will enable a systematic waste collection process for all segregated waste to the Waste transportation phase (TSWMS) through an optimized route system that would apply GIS and Remote sensing technology $(\mathrm{TcS})$, to the waste recycle plant or recovery plant (WMS) for all waste that can be recycled to a resource. The bye products or waste that cannot be recovered are then disposed of after applying multi criteria analysis $(\mathrm{TcS})$ such as distance to river, airport, major roads, advance road, slope, soil type future urban expansion to determine a suitable waste disposal site (TSWMS) for sustainable waste management.

Heavy reliance on government policies and Waste Authorities can be remedied when the public is inculcated into every phase of the solid waste management process. Public education as well as awareness campaigns should be promoted in Nigeria. If every citizen is conscious of the implications his /her waste has on the environment and public health there would be a huge reduction in the volume of waste generated. Education and enlightenment programs are key here and it would facilitate the development of technical know-how on the conversion of waste to resources thereby enlightening more people to embrace new technological strategy skills on areas in the management of waste. While embracing all the benefits of these strategies, the government still have a role to play in establishing a public partnership in the various phases of solid waste management to limit the over-dependence exerted on them for waste management and increase efficiency in the management process, implementing and enforcing SWM policies as well as developing efficient avenues for the acquisition of subsidized technologies that are needed in the waste management process.

This study further recommends the synchronization of all waste management strategies which is evident in the above road map, for the actualization of a sustainable integrated solid waste management strategy for Nigerian Solid Waste Management Authorities and Agencies.

\section{Conclusion}

This study assessed Solid Waste Management (SWM) strategies commonly adopted by different state waste management Authorities in Nigeria with a view to developing a sustainable roadmap for the management of solid waste in Nigeria. It assessed the Traditional Solid Waste Management Strategy (TSWMS), Waste Minimisation Strategy (WMS) as well as the Technological Strategy (TcS) employed, laying focus on their challenges and benefits. The study observed, that waste management across various parts of Nigeria is poor, interwoven with several challenges at all phases of the management process with little benefits recorded on alternative SWM strategy. Although most Waste Authorities rely heavily on the TSWMS, WMS and the TcS showed a better and promising alternative strategy when inculcated into the already existing strategy. This however, can be achieved with a strong public participatory role at all phases of the management process. Based on this finding, a roadmap for the actualization of a sustainable integrated solid waste management strategy framework was recommended for adaptation and adoption by the Nigerian SWM Authorities and Agencies.

\section{References}

Abiodun, A. (2000). Development and utilization of remote sensing technology in Africa. Photogrammetric Engineering and Remote Sensing, 66, 674-686.

Achi, H. A., Adeofun, C.O., Ufoegbune, G. C., Gbadebo, A. M., \& Oyedepo, J. A. (2012). Disposal sites and transport route selection using geographic information system and remote sensing in Abeokuta, Nigeria. Global Journal of Human Social Science Geography \& Environmental Geosciences, 12(12), 15-23

Agunwamba, J. C. (1998). Solid waste management in Nigeria: problems and issues. Environmental Management, 22(6), 849-856. https://doi.org/10.1007/s002679900152.

Aliu, I. R., Adeyemi, O. E., \& Adebayo, A. (2014). Municipal household solid waste collection strategies in an African megacity: Analysis of public private partnership performance in Lagos. Waste Management \& Research, 32(9), 67-78. https://doi.org/10.1177/0734242X14544354.

Aliyu, A. A., \& Amadu, L. (2017). Urbanization, cities, and health: The challenges to Nigeria - A review. Annals of African medicine, 16(4), 149-158. https://doi.org/10.4103/aam.aam_1_17

Aliyu, B. N. (2010) An Analysis of Municipal Solid Waste in Kano Metropolis, Nigeria. Journal of Human Ecology, 31(2), 111-119. DOI: 10.1080/09709274.2010.11906301

Aluko, O. O., Sridhar, M. K. C., \& Oluwande, P. A. (2003). Characterization of leachates from a municipal solid waste landfill site in Ibadan, Nigeria. Journal of Environmental Health Research, 2(1), 32-37.

Amasuomo, E., \& Baird, J. (2016). Solid Waste Management Trends in Nigeria. Journal of Management and Sustainability, 6(4), 35-44. https://doi.org/10.5539/jms.v6n4p35.

Amalu, T. E., \& Ajake, A. O. (2014). Appraisal of Solid Waste Management Practices in Enugu City , Nigeria. Journal of Environment and Earth Science, 4(1), 97-105. 
Amuda, O. S., Adebisi, S., Jimoda, L., \& Alade, A. (2014). Challenges and possible panacea to the municipal solid wastes management in Nigeria. Journal of Sustainable Development Studies, 6(1), 64-70.

Anestina, A., Adetola, A., \& Irhivben, B. (2014). Performance Assessment of Solid Waste Management following Private Partnership Operations in Lagos State, Nigeria. Journal of Waste Management. 1-8. $10.1155 / 2014 / 868072$.

Anifowose, Y. B., Omole, K. E., \& Akingbade, O. (2011). Waste Disposal Site Selection using Remote Sensing and GIS: A Study of Akure and its Environs, Southwest-Nigeria. Proceedings of the Environmental Management Conference, Federal University of Agriculture, Abeokuta, Nigeria (pp. 2-9). Abeokuta: Federal University of Agriculture, Abeokuta.

Asiyanbola, R. A. (2014). Remote Sensing in Developing Country-Nigeria: An Exploration. Journal of Geography and Geology, 6(1), 110-128. https://doi.org/10.5539/jgg.v6n1p110

Awopetu, M. S., Coker, A. O., Awopetu, R. G., Awopetu, S. O., Booth, C. A., Fullen, M. A., Hammond, F. N., \& Tannahill, K. (2013). Reduction, reuse and recycling of solid waste in the Makurdi Metropolitan Area of Nigeria : Public opinions and perceptions. International Journal of Education and Research, 1(11), 1-12.

Ayantoyinbo, B., \& Adepoju, O. (2018). Analysis of Solid Waste Management Logistics and Its Attendant Challenges in Lagos Metropolis. Logistics, 2(2), pp 1-10. https://doi.org/10.3390/logistics2020011.

Ayotamuno, J. M., \& Gobo, A. E. (2004). Municipal solid waste management in Port Harcourt, Nigeria: Obstacles and prospects. Management of Environmental Quality, 15(4), 389-398. https://doi.org/10.1108/14777830410540135.

Babalola, A., \& Busu, I. (2011). Selection of Landfill Sites for Solid Waste Treatment in Damaturu Town-Using GIS Techniques. Journal of Environmental Protection, 2, 1-10. https://doi.org/10.4236/jep.2011.21001.

Babatunde, B. B., Vincent-Akpu, I. F., Woke, G. N., Atarhinyo, E., Aharanwa, U. C., Green, A. F., \& Isaac-Joe, $\mathrm{O}$ (2013). Comparative analysis of municipal solid waste (MSW) composition in three local government areas in Rivers. African Journal of Environmental Science and Technology, 7(9), 874-881. https://doi.org/10.5897/AJEST12.112.

Bakare, W. (2020). Solid Waste Management in Nigeria. Retrieved March 31, 2020, from https://www.bioenergyconsult.com/solid-waste-nigeria/

Bassey, B. E., Benka-Coker, M. O., \& Aluyi, H. S. A. (2006). Characterization and management of solid medical wastes in the Federal Capital Territory, Abuja, Nigeria. African Health Sciences, 6(1), 59-63.

Ben-Iwo, J., Manovic, V., \& Longhurst, P. (2016). Biomass resources and biofuels potential for the production of transportation fuels in Nigeria. Renewable and Sustainable Energy Reviews, 63, 172-192.

Deswal, M., \& Laura, J. S. (2014). Application of GIS in MSW management in India. International Joural of Engineering Research and Development, 10(10), 24-32.

Dutta, D., \& Goel, S. (2017). Applications of remote sensing and GIS in solid waste management-a review. Advances in Solid and Hazardous Waste Management (pp. 133-151). https://doi.org/10.1007/978-3-31957076-1 7

Egbu, A., \& Okkoroigwe, D. (2015). Informal Collection of Household Solid Waste in Three Towns of Anambra State, Nigeria. Present Environment and Sustainable Development, 8(2), 101-116. https://doi.org/10.2478/pesd-2014-0028.

Ezeah, C., \& Roberts, C. L. (2014). Waste governance agenda in Nigerian cities: A comparative analysis. Habitat International, 41(1), 121-128. https://doi.org/10.1016/j.habitatint.2013.07.007.

Fadipe, O. O., Oladepo, K. T., Jeje, J. O., \& Ogedengbe, M. O. (2011). Characterization and analysis of medical solid waste in Osun State, Nigeria. African Journal of Environmental Science and Technology, 5(12), 10271038. https://doi.org/10.5897/AJEST11.130

George, O. (2010). Social effects of poor sanitation and waste management on poor urban communities: a neighbourhood-specific study of Sabon Zongo, Accra. Journal of Urbanism: International Research on Placemaking and Urban Sustainability, 3:2, 145-160, DOI: 10.1080/17549175.2010.502001

Hammed, T. B., Sridhar, M. K. C., \& Wahab, B. (2016). Enhancing Solid Waste Collection and Transportation for Sustainable Development in the Ibadan Metropolis, Nigeria. European Journal of Research in Social Sciences, 4(7), 23-32. www.idpublications.org

Imam, A., Mohammed, B., Wilson, D. C., \& Cheeseman, C. R. (2008). Solid waste management in Abuja, Nigeria. Waste Management, 28(2), 468-472. https://doi.org/10.1016/j.wasman.2007.01.006.

Kaoje, I. U., Dankani, I. M., \& Ishiaku, I. (2016). Site Suitability Analysis for Municipal Solid Waste Disposal in Birnin Kebbi, Nigeria. IOSR Journal of Humanities and social science, 21(7), 1-10. https://doi.org/10.9790/0837-2107030110.

Kofoworola, O. F. (2007). Recovery and recycling practices in municipal solid waste management in Lagos, Nigeria. Waste Management, 27(9), 1139-1143. https://doi.org/10.1016/j.wasman.2006.05.006

Leton, T., \& Omotosho, O. (2004). Landfill operations in the Niger delta region of Nigeria. Engineering Geology, 73(1), 171-177. https://doi.org/10.1016/j.enggeo.2003.12.006 
Longe, E., Longe, O., \& Ukpebor, E. (2009). People's Perception on Household solid waste management in Ojo Local Government Area, in Nigeria. Iranian Journal of Environmental Health Science \& Engineering, 6, 209-216.

Maiyaki, M. A., Marzuki, A., \& Mustafa, R. (2018). A Review of rationale of community participation in urban solid waste management in Nigeria. International Transaction Journal of Engineering, Management, \& Applied Sciences \& Technologies, 9(3), 185-196.

Mazhindu, E., Gumbo, T., \& Gondo, T. (2012). Waste Management Threats to Human Health and Urban Aquatic Habitats - A Case Study of Addis Ababa, Ethiopia, Waste Management - An Integrated Vision, IntechOpen, DOI: 10.5772/48077. Available from: https:/www.intechopen.com/books/waste-management-an-integratedvision/waste-management-threats-to-human-health-and-urban-aquatic-habitats-a-case-study-of-addisababa-ethi

Momodu, N. S., Dimuna, K. O., \& Dimuna, J. E. (2011). Mitigating the Impact of Solid Wastes in Urban Centres in Nigeria. Journal of Human Ecology, 34(2), 125-133. DOI: 10.1080/09709274.2011.11906377

National Bureau of Statistics. (2018). Demographic Statistics Bulletin (p. 7). Abuja, FCT: National Bureau of Statistics.

National Environmental Standards and Regulations Enforcement Agency. (2007). National Environmental Standards and Regulations Enforcement Agency (Establishment) Act. Retrieved March 31, 2020, from http://extwprlegs1.fao.org/docs/pdf/nig120569.pdf

Nguyen-Trong, K., Nguyen-Thi-Ngoc, A., Nguyen-Ngoc, D., \& Dinh-Thi-Hai, V. (2016). Optimization of municipal solid waste transportation by integrating GIS analysis, equation-based and agent-based model. Waste Management. http://dx.doi.org/10.1016/j.wasman.2016.10.048.

Nishant, T., Prakash, M. N. and Vijith, H. (2010). Suitable site determination for urban solid waste disposal using GIS and remote sensing techniques in Kottayam Municipality, India. International Journal of Geomatics and Geosciences. 1 (2): 197-210

Nnaji, C. C. (2015). Status of municipal solid waste generation and disposal in Nigeria. Management of Environmental Quality: An International Journal, 26(1), 53-71. https://doi.org/10.1108/MEQ-08-2013-0092.

Nwosu, O. A., \& Okoye, O. C. (2019). Assessment of public participation in household waste management in Awka metropolis, Anambra state, Nigeria. IOSR Journal of Environmental Science, 13(6), 89-102. https://doi.org/10.9790/2402-13060289102

Nzeadibe, T. C. (2009). Solid waste reforms and informal recycling in Enugu urban area, Nigeria. Habitat International, 33(1), 93-99. https://doi.org/10.1016/j.habitatint.2008.05.006

Nzeadibe, T. C., \& Anyadike, R. N. C. (2012). Social participation in city governance and urban livelihoods: Constraints to the informal recycling economy in Aba, Nigeria. City Culture \& Society, 3(4), 313-325. https://doi.org/10.1016/j.ccs.2012.10.001.

Olanrewaju, O. O., \& Ilemobade, A. A. (2009). Waste to wealth: A case study of the Ondo state integrated wastes recycling and treatment project, Nigeria. European Journal of Social Sciences, 8(1), 7-16.

Oguntoyinbo, O. O. (2012). Informal waste management system in Nigeria and barriers to an inclusive modern waste management system: A review. Public Health, 126(5), 441-447. https://doi.org/10.1016/j.puhe.2012.01.030

Ogwueleka, T. C. (2009a). Route optimization for solid waste collection: Onitsha (Nigeria) case study. Appl. Sci. Environ. Manage, 13(2) 37 - 40

Ogwueleka, T. C. (2009b). Municipal solid waste characteristics and management in Nigeria. Iranian Journal of Environmental Health Science \& Engineering, 6(3), 173-180.

Ojo, J.S., Olorunfemi, M.O., Bayode, S., Akintorinwa, O.J., Omosuyi, G.O., \& Akinluyi, F.O. (2014). Constraint map for landfill site selection in Akure metropolis, Southwestern Nigeria. Ife Journal of Science 16(2), 405416.

Olanrewaju, O. O., \& Ilemobade, A. A. (2009). Waste to wealth: A case study of the Ondo state integrated wastes recycling and treatment project, Nigeria. European Journal of Social Sciences, 8(1), 7-16.

Oloruntade, A. J., Adeoye, P. A., \& Alao, F. (2014). Municipal solid waste collection and management strategies in Akure, South-Western Nigeria. Journal of Solid Waste Technology and Management, 40(1), $24-32$. https://doi.org/10.5276/JSWTM.2014.24

Olukanni, D. O., Adeleke, J. O., \& Aremu, D.D. (2016). A Review of Local Factors Affecting Solid Waste Collection in Nigeria. Pollution, 2(3), 339-356. https://doi.org/10.7508/pj.2016.03.008.

Olukanni, D. O., Aipoh, A. O., \& Kalabo, I. H. (2018). Recycling and reuse technology: Waste to wealth initiative in a private tertiary institution, Nigeria. Recycling, 3(3), pp 1-12. https://doi.org/10.3390/recycling3030044.

Olukanni, D. O., \& Mnenga, M. U. (2015). Municipal Solid Waste Generation and Characterization : A Case Study of Ota , Nigeria. International Journal of Environmental Science and Toxicology Research, 3(1), 1-8.

Onuigbo, C. I., \& Bello, E. A. (2014). Assessment and Selection of Suitable Sites for Solid Waste Disposal using Surveying and Geoinformatics Techniques. International Journal of Engineering Research \& Technology 
(IJERT), 3(8), 1685-1692.

Onwughara, I. N., Nnorom, I, C., \& Kanno, O. C. (2010). Issues of Roadside Disposal Habit of Municipal Solid Waste, Environmental Impacts and Implementation of Sound Management Practices in Developing Country "Nigeria". International Journal of Environmental Science and Development Vol.1, No.5, 409-418.

Onwurah, I. N. E., Ogugua, V. N., \& Otitoju, O. F. (2006). Integrated environmental biotechnology-oriented framework for solid waste management and control in Nigeria. International Journal of Environment and waste management, 1(1), 94-104.

Oyeniyi, A. B. (2011). Waste Management in Contemporary Nigeria : The Abuja Example. International Journal of Politics and Good Governance, 2(2), 1-18. http://onlineresearchjournals.com/ijopagg/art/73.pdf.

Oyinloye, M. A., \& Tokunbo, M. F. (2013). Geo-Information for Urban Waste Disposal and Management: The Case Study of Owo LGA, Ondo State, Nigeria. The International Journal of Engineering and Science (IJES), 2(9), 19-31.

Rigasa, Y. A., Abdulkarim, B. I., Badamasi, A. G. (2015). Waste management services: A strategy for the integration of 'Almajiri' into current waste management action plans of urban centres in northern Nigeria. Biological and Environmental Sciences Journal for the Tropics, 12(1), pp 558-565.

Saghir, J., \& Santoro, J. (2018). Urbanization in Sub-Saharan Africa:Meeting Challenges by Bridging Stakeholders. $\quad$ Retrieved from https://csis-prod.s3.amazonaws.com/s3fspublic/publication/180411_Saghir_UrbanizationAfrica_Web.pdf?o02HMOfqh99KtXG6ObTacIKKmRvk0 Owd.

Sha'Ato, R., Aboho, S. Y., Oketunde, F. O., Eneji, I. S., Unazi, G., \& Agwa, S. (2007). Survey of solid waste generation and composition in a rapidly growing urban area in Central Nigeria. Science Direct: Waste Management q. 27, 352-358. https://doi.org/10.1016/j.wasman.2006.02.008

Shoba, B., \& Rasappan, K., (2013). Application of GIS in solid waste management for Coimbatore City. International Journal of Scientific and Research Publications, 3(10), pp 1-4.

Singh, R. P., Singh, P., Arouja, A. S. F., Ibrahim, M. H., \& Sulaiman, O. (2011). Management of Urban Solid Waste: Vermin composting a sustainable option. Resource. Conserv. Recycl. 55, 719-729.

Solomon, U. U. (2009). The state of solid waste management in Nigeria. Waste Management, 29(10), 2787-2788. https://doi.org/10.1016/j.wasman.2009.06.030

Somorin, T. O., Adesola, S., \& Kolawole, A. (2017). State-level assessment of the waste-to-energy potential (via incineration) of municipal solid wastes in Nigeria. Journal of Cleaner Production, 164, 804-815. https://doi.org/10.1016/j.jclepro.2017.06.228

Suberu, M. Y., Mokhtar, A. S., \& Bashir, N. (2012). Renewable power generation opportunity from municipal solid waste : A case study of Lagos metropolis (Nigeria). Journal of Energy Technologies and Policy, 2(2), $1-15$.

State of Vermont Agency of Natural Resources Department of Environmental Conservation. (2012). Solid Waste Management Rules (8th Ed., Vol. 1 ). Retrieved from Https://Dec.Vermont.gov/sites/dec/files/wmp/SolidWaste/Documents/SWRule.final_.pdf

The World Bank. (2019). Solid Waste Management. Retrieved from https://www.worldbank.org/en/topic/urbandevelopment/brief/solid-waste-management.

Thompson, A. F., Afolayan, A. H., \& Ibidunmoye, E. O. (2013). Application of Geographic Information System to Solid Waste Management. Pan African International Conference on Information Science, Computig and Telecommunications. https://doi.org/10.1109/SCAT.2013.7055110

Udoh, I. B., \& Inyang, S. A. (2016). Purview of Public Solid Waste Collection, Disposal and Management Practices in Akwa Ibom State. International Research Journal of Environmental Sciences, 5(7), 55-63.

Usman, A. A., \& Kumar, M. (2015). Site suitability analysis for waste disposal in Kano Metropolis, Nigeria (Using multi-criteria evaluation, AHP, and GIS techniques). International Journal of Scientific \& Engineering Research, 6(11), 1072-1081.

Uwadiegwu, B. O. (2013). Strategies for Effective Urban Solid Waste Management in Nigeria. European Scientific Journal, 9(8), 296-308.

Wahab, B., \& Kehinde, O. (2014). Street sweeping in Ibadan: Urbanizing Yoruba traditional environmental sanitation practice. African Journal of Sustainable Development, 4(1) 87-101

Zumo, I. M., \& Vokna, S. A. (2014). Identification of suitable site for solid waste disposal in Yola, Nigeria Using GIS method. FIG Congress: Engaging the Challenges-Enhancing the Relevance (pp. 16-21). Kuala Lumpur, Malaysia. 